\title{
仮想空間における立体視のための光跡表現
}

\section{A Stereoscopic Representation of Shafts of Light in Virtual Environments}

\author{
中村 亜希子†, \\ 橋本直已垪，正会員 中嶋 正之†
}

Akiko Nakamura $^{\dagger}$, Naoki Hashimoto ${ }^{\dagger \dagger}$ and Masayuki Nakajima ${ }^{\dagger}$

\begin{abstract}
A representation of shafts of light in Computer Graphics $(\mathrm{CG})$ allows us to create high quality images that are beautiful and realistic. However, previous methods to represent these shafts of light take a lot of calculation time and are ineffective for stereoscopic viewing. Therefore,is difficult to using these methods for interactive applications in 3-D virtual environments. We describe a new method to create shafts of light for interactive 3-D applications using stereoscopic images. In this method, the intensity distribution of light is calculated for some texture images, and these images are mapped on a 3-D object that represents the shape of shafts of light. By using a texture mapping function for graphics hardware, the tota! performance is accelerated enough for interactive applications.
\end{abstract}

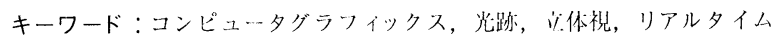

\section{1.は じめに}

CG (Computer Graphics) における光の表現は, 光 特有の神秘的な美しさと現実感を高める効果が相乘し て質の高い映像表現を可能にする。このため, 映画や アート作品において CGによる光の表現が効果的に利用 されている。しかし，リアルタイム性の要求される VR (Virtual Reality)においては, CGによる光の表現を取 り入れ，リアルタイムで処理することは依然として困 難である．近年のグラフィックスハードウェアの進化は 目覚しく, 様々な映像効果をリアルタイムに表現可能と なっており，また，CAVEのような大型仮想環境システ ムも徐々に普及していることから，インタラクティブな 映像環境においても，より現実感の高い仮想空間を実現 をする光のリアルタイムなレンダリング処理への需要は 今後ますます高まっていくことが予想される.

そこで本研究では，仮想空間においてインタラクショ ンを行うことを想定し, 奥行き感を持った光跡を高速に レンダリングする手法を提案する。このとき，スポット ライトのような点光源から円錐状に広がる光跡の奥行き

2002 年 10 月 31 日受付, 2003 华 3 J 28 日怗受付, 2003 年 4 月11 日採録 †東宗1業大学大学院情報理.学研究科

( ₹ 152-8552 H黑区大阔川 2-12-1, TEL 03-5734-2183)

†十東京以業大学 精密门学研究科

( ₹ 226-8503 横浜沛緑区長津四町 4259, TEL 045-924-5050)

† Graduate School of Information Science \& Engineering, Tokyo Institute of Technology

(2-12-1 Ookayama Meguroku, Tokyo 152-8552, Japan)

$\dagger+$ Precision and Intelligence Laboratory, Tokyo Institute of Technology

(4259 Nagatsuta, Midori-ku, Yokohama 226-8503, Japan)
感を実現することを目的とする. 3 次元仮想空間におい て，奥行きのない光跡をレンダリングすると，その他に 表示されている物体と比較して違和感を感じてしまう。 光跡とは，光の表現方法の一つであり，大気中の塵や埃 などによって光が散乱されて大気中に光の筋が見える現 象である、レイトレーシング等による光跡表現 ${ }^{11}$ は膨大 な計算時間を必要とし，インタラクティブ性を重視した 3 次元仮想空間に扔ける応用には適していない。また， ハードゥェアアクセラレーション機能を利用した高速な 光跡表現手法 ${ }^{2)}$ も提案されているが，仮想空間における 光跡の 3 次元的な広がりを表現することが困難である.

上述した問題を解決するために，ハードウェアアクセ ラレーション機能によって高速に生成された光跡の輝度 分布をテクスチャ情報として取得し，これを光跡の空間 的分布を表現する 3 次元モデルにマッピングすることで， 奥行き感を伴った光跡表現を実現した。提案手法を用い ることにより，従来のリアルタイム $3 \mathrm{DCG}$ では実現が 困難であった，奥行き感を持つ光跡を利用した照明効果 を，簡単かつ高速に実現することが可能になった。

\section{2. 従来の光跡レンダリング手法}

従来から，CGにおいて高い映像効果を実現する光の レンダリングに関する研究は数多く試みられている。こ れらの表現の手法の一つとして, 光跡をレンダリングす るための手法もいくつか提案されており, 光の通過する 領域を追跡するレイトレーシング法 ${ }^{1)}$ ，フォトンマップ

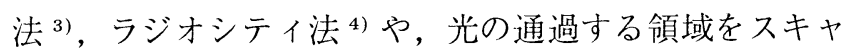
ンラインから追う手法 ${ }^{5}$ が広く用いられている。フォ 
トンマップ法やラジオシテイ法では，光を散乱する効果 を持たせたある媒体を空間内に放つことによって，光の 散乱の結果である光跡をレンダリングすることを可能 としている。またスキャンライン法では，影になる部分 を Shadow Volumeを用いて算出するという特徵を持つ. しかし, 今までに挙げた手法では精度の高い画像を生成 できる反面，画像生成に多くの計算時間を必要とする. よって, 仮想空間でのインタラクションを行うための光 跡レンダリング手法には適していない.

一方，レンダリング時間の短縮を目的として，グラ フィックスハードウェアを用いて高速に光跡をレンダリ

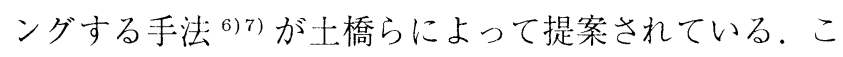
の手法では, 光跡の高速なレンダリングが可能となり, 光跡内の影も表現可能である。また，安価なグラフィッ クスハードウェアを利用して，高速な光跡レンダリング を実現することができる。しかし，仮想空間での立体視 を考慮していないため, インタラクティブな没入型仮想 空間において耐眼立体視を行った場合に，適切な両眼立 体視差を生成することができない，以上の理由から，奥 行き感を持つ光跡を高速にレンダリングする手法の実現 が望まれている。

\section{3. 光跡表示アルゴリズムの概要}

本節では，仮想空間でのインタラクションを想定した 光跡表示アルゴリズムを提案する．光跡のレンダリング 手法に求められる要素としては, レンダリング速度, 奥 行き感, 滑らかな輝度变化等が挙げられる。 上述した要 素のうち，仮想空間において光跡を用いることを考慮す ると,リアルタイムに画像を生成することが可能なレン ダリング速度が必要となる。ささらに、ユーザとのインタ ラクションを行うためには, 視点に依存しない奥行き感 と輝度变化を実現する必要がある。よって, 本研究で提 案する光跡レンダリング手法が満たす必要のある要素は, 以下の通りである。

·視線方向, 視点位置に影響されない奥行き感

・視線方向, 視点位置に影響されない滑らかな輝度 変化

・リアルタイムな画像生成を可能とするレンダリング 速度

上述の要素を考虑して，2節で挙げた関連研究を特徵 毎に比較したものを表 1 に示す。本提案アルゴリズムで は, 視線方向, 視点位置に影響されない奥行き感と滑ら かな輝度変化を実現するために, 3 次元モデルを導入す る。一般的に，人間が奥行き感を感じる主な要因の一つ として, 両眼視差が挙げられる。仮想空間においても, 両眼視差を再現することで, 高い奥行き感を実現するこ とができる. 光跡レンダリング時に上述の両眼視差を与. えることによって, 光跡の奥行き感を与える.このため には, 光跡の空間的な広がりの情報を維持したまま光跡
表 1 光跡レンダリングき法の特徽比較 The feature comparison of shafts of light rendering technique.

\begin{tabular}{|c|c|c|c|}
\hline & レンダリング速度 & 滑らかな輝度変化 & 奥行き感 \\
\hline レイトレーシング & $\triangle$ & 0 & $x$ \\
\hline フォトンマップ & $\triangle$ & (a) & $x$ \\
\hline ハードリェアアクセラレーション & O & 0 & $x$ \\
\hline
\end{tabular}

の輝度を計算し， 3 次元仮想空間内に配置することが必 要となる。これらの条件を考慮して, 本研究で奥行き感 を表現するために採用した 3 次元モデルを, 光跡基準形 状と呼ぶ.

次に,リアルタイムなレンダリング速度を実現するた めに, 光跡の輝度を求める部分でグラフィックスハード ウェアを利用し，高速に輝度を計算する。ここでは， 2 節で述べた, グラフィックスハードウェアを利用して, 高速に輝度を計算する土橋らの手法 7)を用いる. 光跡 の輝度分布を計算するためには, 大気中の塵などの微粒 子による散乱光を視線に沿って積分する必要がある ${ }^{8)}$. 視線上のある一点に注目した場合, 注目点の散乱光の 強さを求めるための要素として, 光源から注目点の方 向一発せられる光の強さを表す配光特性や, 光源から の距離と視点からの距離に影響される光の減衰率が挙 げられる。前者は Projective Texture Mapping, 後者は Multitexture, 視線に沿って各注目点の散乱光の強さを 近似的に積分するために Alpha Blending を用い, グラ フィックスハードウェアの機能を利用して高速に計算す る。この土橋らの手法では, 散乱光を視線に沿って積分 する部分で, 仮想的な平面を利用して輝度を数值積分し ている. 平面を利用すると, 光跡の空間的な広がりの情 報が損なわれてしまい，両眼視差を含んだ映像を生成す ることは困難である。

本研究では, 上述した光跡基準形状を用いることで, 光跡の空間的な広がりの情報を維持したまま輝度の数值 積分を行う，光跡基準形状を用いるにあたって，考虑し なければならないこととして, 光跡の輝度がある部分に は, 輝度を計算するための 3 次元モデルを等間隔に配置 する必要がある，ということである。例えば， 3 次元モ デルとして円錐を用いた場合, 3 次元モデルが等間隔に 配置されないため, 図 1 のように滑らかな輝度変化が失 われてしまう。図1の右図の一部を拡大したものを図 1 左に示した。

ここで, 土橋らの手法と本研究での提案手法を比較し たものを，図 2 に示す.テクスチャをマッピングする領 域が減少したことで, 提案手法ではレンダリング速度が 向上した。

これ以降, 光源からの光が減衰しないと仮定した場合 に, 光が通過する範囲を, 光跡の表示範囲と呼ぶ。この とき, 光跡基準形状は光跡の表示範囲に配置される必要 がある. 本提案アルゴリズムの詳細については, 後の 4 


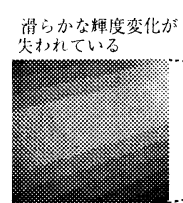

搪大网

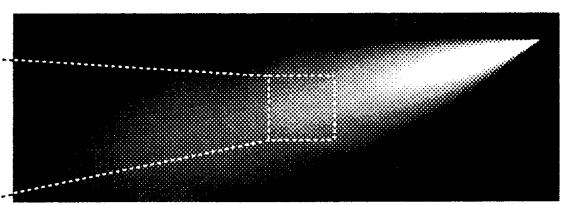

絬果画像
図 13 次元モデルとして[1錐を朋いた埸介 Use cone model for 3D model.

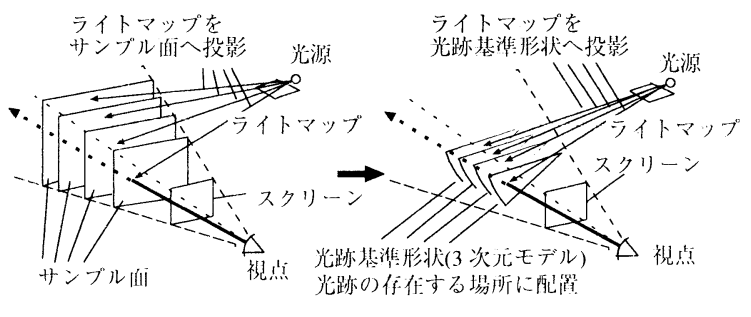

蔇份丁泣

提婪和法

図 2 撚你丁法之提栄于泣

Exist method and proposed method.

節で述べる。

\section{4. 仮想空間における輝度分布と光跡基準形状}

本節では，まず始めに 3 節で述べた光跡基準形状を用 いて光跡のレンダリングを行う手法について述べる. 次 に, ユーザとのインタラクションを想定した場合に, 光 跡の自由な移動と回転を実現する手法について述べる。

\section{1 光跡基準形状を用いた光跡のレンダリング}

まず始めに, 光跡の表示範用を求める。次に, 視点か ら見える光跡の表示範囲を覆うような 3 次元モデルを用 意する．光跡の奥行き感に最も大きな影響を与えている のは, 視点から見て一番近い所に存在し, かつ, 輝度を 有した形状である。 そこで, この形状を 3 次元モデルで 近似することで光跡の奥行き感を表現する．このように して得られた 3 次元モデルが, 光跡基準形状となる. 続 いて, 3 次元仮想空間内の光跡表示範囲を覆う位置に 1 つめの光跡基準形状を配置し, 仮想空間内の輝度を等間 隔に計算して積分するために，光跡基準形状と同じ形の 3 次元モデルを, 光跡の中心軸に対して平行移動し, 等 間隔に複数個配置する。これは, 輝度計算時の数值積分 を行う際に，均等な条件を揃えることによって，精度の 高い光跡を表示するためである.このときの光跡基準形 状の配置の様子を図 3 に示寸.

次に, 光跡の輝度を計算する方法について述べる。 ま ず，各基準形状をメッシュ状に分割し，各メッシュに対 して配光特性および減衰率を計算して輝度分布を求める。 この際，配光特性は光源の輝度に応じたライトマップ を, 光源の向きを考慮して光跡基準形状にプロジェクト するようにテクスチャ座標を自動生成し，プロジェクト されたライトマップの值から計算する。 さらに, Alpha Blending を用いて, 各光跡基準形状の輝度を足し合せる
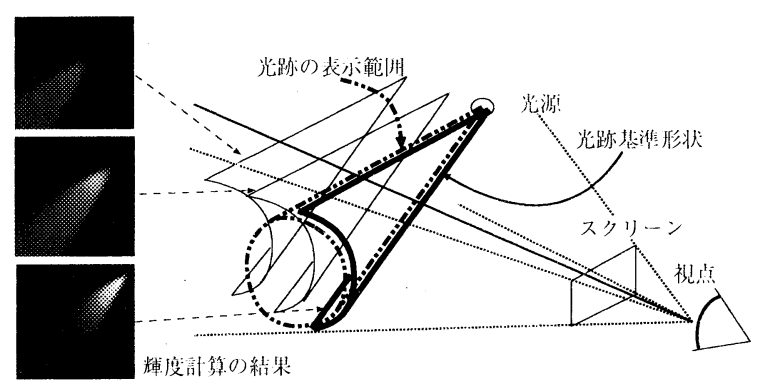

図 3 光跡基潐形状の配刿

Arrangement of shafts of light model.

ことによって，奥行き感と光跡全体の輝度を表現する。

この光跡基準形状を用いることで, 光源からの光がス クリーンに直接あたらない場合，すなわち，スクリーン と光跡の表示範囲が交わらない場合に，光跡の奥行き感 を表すことができる．しかし，光跡基準形状を用いた場 合でも，スクリーンと光跡の表示範囲が交わる場合には， 対応できない. そこで, 光跡の向いている方向によって は, 光跡基準形状以外の 3 次元モデルを考える必姴が ある。

\section{2 光跡基準形状の拡張}

本提案アルゴリズムでは，光跡基準形状では表現でき ない部分を補うために，3次元モデルとして球を採用す る。以下に球を採用する主な理由を述べる。第 1 に，テ クスチャ座標を計算する場合の計算量を減少させること が可能である．第 2 に，光源からの光が向いている方向 が，視点方向である場合に光跡の立体感を得ることがで きる. 第 3 に, 光源からの光が向いている方向が視点方 向である場合に, 滑らかな輝度変化が得られる。実際に は円錐等, 他の形状を持つ 3 次元モデルでのレンダリン グも行ったが，球を用いることによってレンダリング速 度と輝度の滑らかな変化の両方の要素をバランスよく満 たすことができたため，球を採用した。

球を用いて光跡をレンダリングするときの基本概念 を図4(a)に示す。まず始めに，光源位置を中心として， 半径を等間隔に増やしながら，球を複数個配置する。光 が向いていない方向には，ポリゴンを配置する必要がな いので, 半球を複数個配置すると, レンダリング速度を 向上させることが可能となる。そ㞦ぞれの球をメッシュ 状に分割し，各メッシュに対して輝度を計算する。メッ シュ状に分割するとき，図4(b)のように分割する。これ は，一番輝度変化が大きい部分に対し細い分割を行うた めである。

また, 球形を 3 次元モデルとして採用した場合, 配光 特性を計算するときに，ライトマップをプロジェクトす るように, テクスチヤ座標の自動生成をする必要はな い. ある点の配光特性の值が, その点から光跡の中心軸 に降ろした垂線の長さに比例することを利用してテクス チャ座標を求めることにより，ハードウェアによるテク 


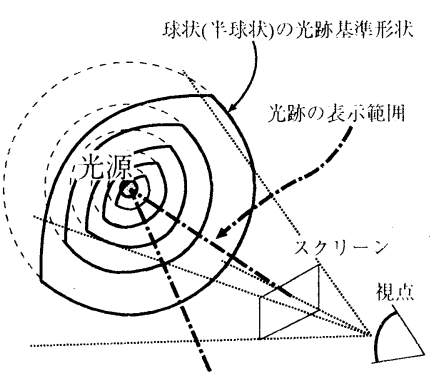

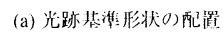

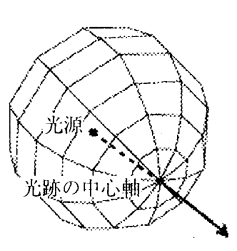

(b) 球のメッシュ分割

図 4 球を用いた光跡のレンダリング Shafts of light rendering in using sphere model.

スチャ座標の自動生成を行うよりも, 計算量を減少させ ることができる。以上の作業により, 光源からの光が視 線方向を向いている場合に, 奥行き感と滑らかな輝度变 化を持った光跡をレンダリングすることが可能となる.

\section{3 光跡の自由な移動と回転}

本項では, 視線方向, 視点位置に影響されない奥行き 感と滑らかな輝度を実現するための手法について述べる. この 2 つの要素を実現することによって，光跡の自由な 回転と移動が可能になる。

4.1 節で述べたように，奥行き感を持つ光跡のレンダ リングアルゴリズムとしては，光跡基準形状を用いる手 法が有効である。しかし，光跡基準形状を用いる手法で は，光源からの光が視線方向を问いた場合に，滑らかな 輝度变化が得られない. 滑らかな輝度变化が头われてい る様子を図 5(a) に示す。ユーザとのインタラクション の過程で滑らかな輝度変化が失われることは望ましくな いため, 光源からの光が向いている方向と視点位置の関 係から，光跡を表示するために用いる 3 次元モデルを使 い分ける必要がある。

光跡基準形状を用いている場合に, 輪郭が目立つのは, 光跡の表示範囲とスクリーンが交わるときである。この ときに，光跡基準形状がスクリーンにより切断され，切 断面がエッジとして結果画像に残る結果となる。光跡の 表示範囲とスクリーンが交わる場合の位置関係の一例を 図 5(b) に示す。

このような状況を避けるため，光跡基準形状の拡張を 用いて, 光跡の表示範囲とスクリーンが交わる場合は球, それ以外の場合には, 光跡の表示範囲を覆う形の光跡基 準形状を用いることによって, 視点位置や光源からの光 の向きに影響されずに，光跡の滑らかな輝度変化と奥行 き感を保つことが可能となる。

\section{5. 光跡の立体表示の実現結果}

本節では，提案した手法に対して仮想空間で光跡を 用いる場合に必要とされる要素各々に対して評価，お よび考察を行った。ここで用いた環境では，CPUとし て Pentium4 2GHz を搭載したPCに, NVIDIA 社の GeForce3 搭載のグラフィックスボードを使用した。立体

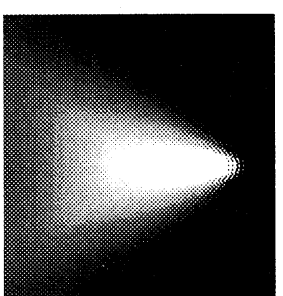

(a) 輪郭画像

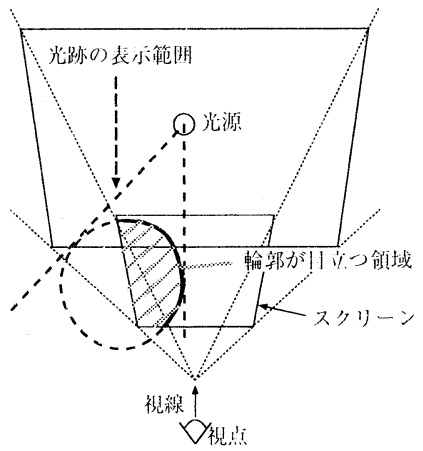

(b) 輪垶が川方位崖関係
図 5 个月移動と问垃

Free movement and free rotation.

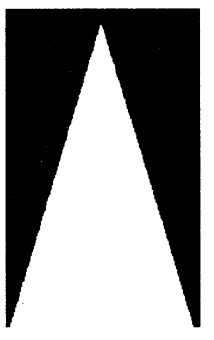

(a) 光跡の表小範閒

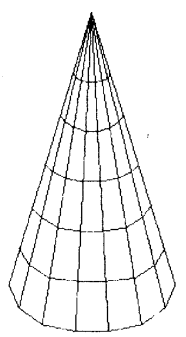

(b)3 次匹モデル

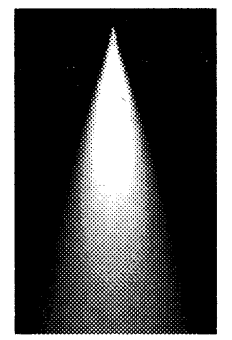

(c)最終結果淌像
図 6 光跡基潐形状を川いた光跡レンダリング過程 Rendering process in using shafts of light model.

視は，ELSA 社の 3D REVERATORを用いて，17イ ンチ CRTディスプレイ上で行った。

\section{1 光跡の奥行き感の実現}

光跡基準形状を用いる提案手法によって光跡表現を 行った結果を図 6 に示す. 図 6(a) は光跡の表示範讲を 日，光跡の表示範囲外を黒で示したものである。図 6(b) は (a)の範囲を覆うように用意された光跡基準形状の概 形である。このとき，光源からの光は真下を向いている ので，光跡基本形状は下が底面となるような円錐の視点 から見える部分をポリゴンで近似したものとなる。この 光跡基本形状を複数個配置し，それぞれ輝度を計算して 得られた結果が図 6(c) である。

光跡基準形状を利用することによって，テクスチャの 適用領域が減少したことから高速化が可能となり，20fps の描画速度を得ることができた。さらに，被験者 6 名に よる奥行き感に関する評価実験を行った。提案手法と既 存手法 ${ }^{7)}$ をそれぞれ 5 秒ずつ表示し，これを 1 セットと して 10 回繰り返した。提示する順はランダムに決定し 立体視をしてもらった結果，より奥行き感を感じられる 光跡を選択させた，実験結果を表 2 に示す．被験者 6 名 中， 5 名が提案手法による光跡が，より奥行き感を感じ ると評価しており，被験者全体において提案手法が支持 された割合は $81.6 \%$ あった。以上に示された通り，提 案手法を用いて光跡を表示した場合，より強い奥行き感 を表現することが可能となる。 
表 2 提案丁法と従来丁:法の奥行き間に関する比較

The stereoscopic image comparison of proposed method and exist method.

\begin{tabular}{c||c|c|c|c|c|c}
\hline \hline 被験者 & $\mathrm{A}$ & $\mathrm{B}$ & $\mathrm{C}$ & $\mathrm{D}$ & $\mathrm{E}$ & $\mathrm{F}$ \\
\hline 提案手法を支持した割合 & $100 \%$ & $60 \%$ & $100 \%$ & $90 \%$ & $40 \%$ & $100 \%$ \\
\hline
\end{tabular}

\section{2 輝度変化とレンダリング速度}

本研究で提案する手法において，レンダリング速度に 影響を与えている要素として, 光跡基準形状の数, 光跡 基準形状の分割数などが考えられる。これらの要素は主 にユーザにより指定される。

レンダリング速度と光跡基準形状数は反比例するた め, 画質を向上させるとレンダリング時間を多く必要と する. 分割数も同様で, 3 次元モデルの分割数を増加さ せれば画質も向上するが，計算時間を多く必要とするよ うになる。よって, 光跡基準形状の数や分割数を状況に 応じて変化させることによって，画質とレンダリング速 度のどちらを優先するかを選択できるようにするのが望 ましい.

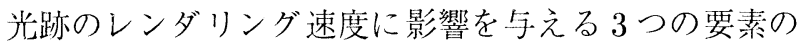
うち, 分割数と光跡基準形状の数を変化させた際の光跡 の表示結果を示す. 光跡基準形状の分割数を变化させた ときの結果画像を図 7 , また, その際のレンダリング速 度の变化を表 3 に示す. 同様に, 光跡基準形状の個数を 変化させたときの結果画像を図 8 に示し, そのレンダリ ング速度変化を表 4 に示す。

一般的に仮想空間でのインタラクションに必要とされ るレンダリング速度は，15fps〜30fps である．以上の結 果より，仮想空間でのインタラクションを想定した場合 に必要とされる 20.0fps 程度のレンダリング速度を維持 したまま, 体験者に対して違和感の少ない結果画像を, 表示することが充分可能であると言える. さらに，提案 手法では分割数や光跡基準形状の個数を容易に変更でき るため, 画質とレンダリング速度のどちらを優先するか,

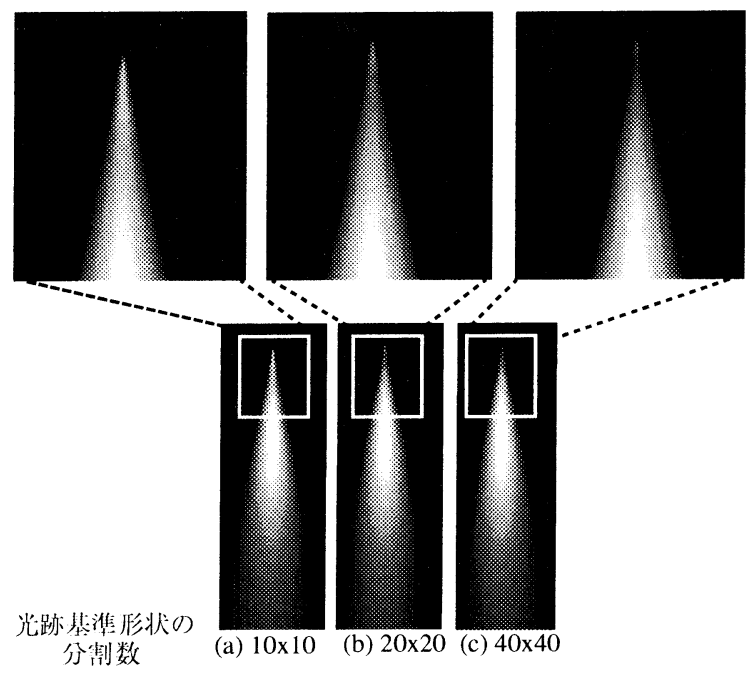

図 7 光跡基潐形状の分割数変化と結果画像 The number of division of model and result.

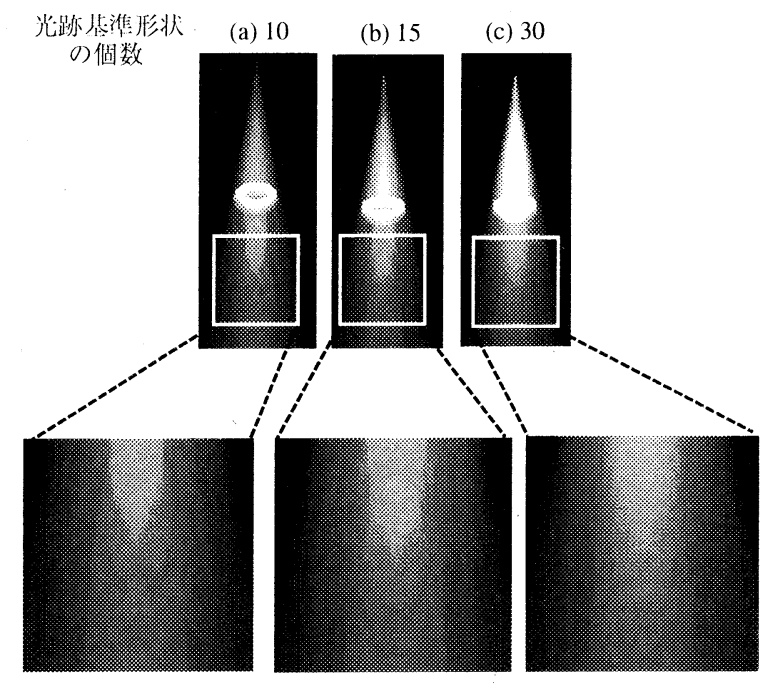

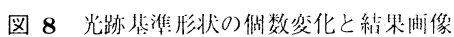
The num of models and result.

表 3 分制数変化とレンダリング速度

The number of division of model and rendering speed

\begin{tabular}{c||c|c|c}
\hline \hline |冈 7 & $(\mathrm{a})$ & $(\mathrm{b})$ & $(\mathrm{c})$ \\
\hline 3 次心モデルの数 & 15 㑬 & 15 㑬 & 15 佔 \\
\hline 分制数 & $10 \times 10$ & $20 \times 20$ & $40 \times 40$ \\
\hline レンダリング速度 & $85.6 \mathrm{fps}$ & $25.6 \mathrm{fps}$ & $11.9 \mathrm{fps}$ \\
\hline
\end{tabular}

表 4 光跡基售䚲状の做数変化とレンダリング速度

The num of models and rendering speed.

\begin{tabular}{|c|c|c|c|}
\hline 仪 8 & (a) & (b) & (c) \\
\hline 3 次儿もデルの数 & 10 湖 & 15 佔 & 30 㑉 \\
\hline 分制数 & $20 \times 20$ & $20 \times 20$ & $20 \times 20$ \\
\hline レンダリング 速度 & $39.0 \mathrm{fps}$ & $26.1 \mathrm{fps}$ & $13.2 \mathrm{fps}$ \\
\hline
\end{tabular}

状況に応じて変更することが可能である，よって，様々 な仮想環境において立体視を伴った光跡を用いることが 可能となり，既存手法と比較して，インタラクションに 向いていると考えられる。

\section{3 提案手法を用いた様々な照明効果}

ライトマップとして様々なテクスチヤを用いることに よって，多様な照明効果を実現することが可能である。 シャドウマップを用いて，仮想空間内にある他の物体 との干渉が発生したときの結果画像を図 9 に示す。画 像サイズが 1600pixels × 1200pixels の場合，描画速度 $23.0 f p s$ を実現している。

6. おわりに

本研究では，リアルタイム性を要求される仮想環境に おける光跡表現の高速で実用的なレンダリング手法を提 案した。光跡の奥行き感に注目し，奥行き感と光跡の滑 らかな輝度变化を実現するのに適した 3 次元形状を導入 した。これにより，リアルタイムでの光跡のレンダリン グが可能となった。

今後の課題としては, 光跡と実物体とのインタラク ション等を取り入れたり, 光跡と仮想物体との干渉時に 生じる輝度変化部分の円滑化等が挙げられる。 


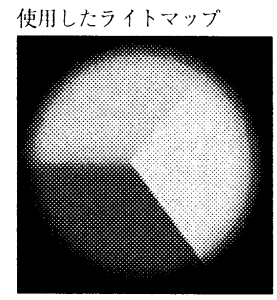

\section{結果画像}
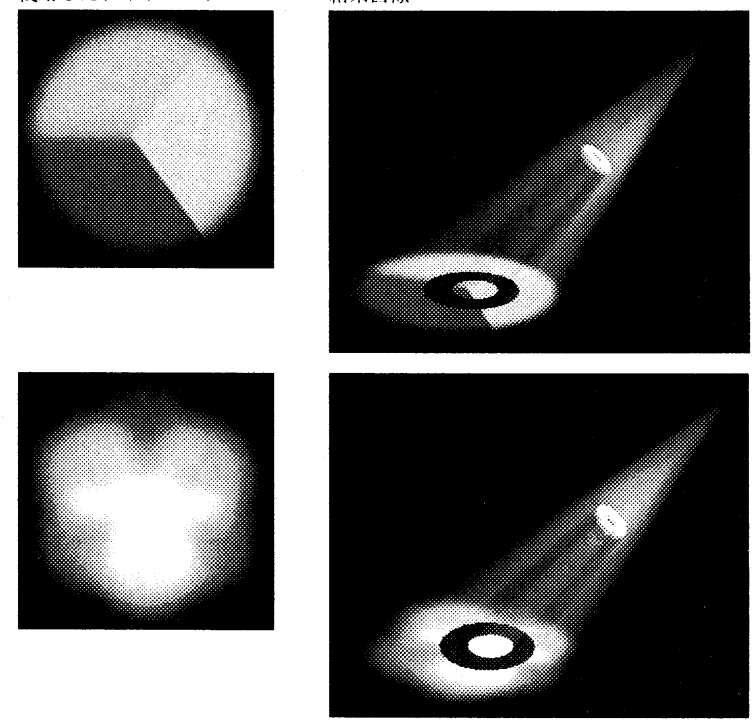

図 9 様々な鯊朾効果

Various lighting effects.
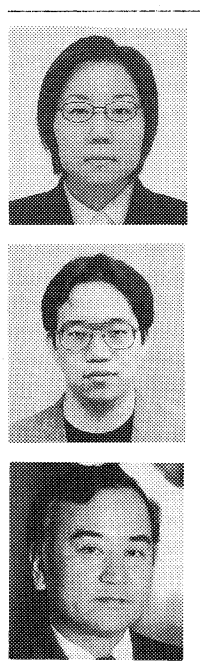

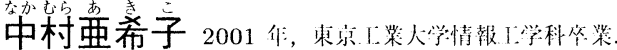

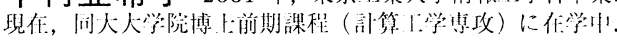
トとしてNPR に関立る研究に煺拉。

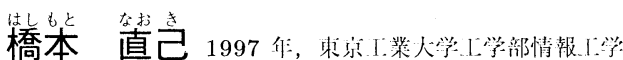

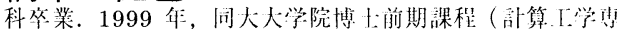
攻）修厂. 2001 作，同大大学院博七後期課程（胡算.1学照

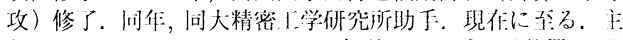
としてバーチャルリアリティ・大型ディスブレイ装衤に同

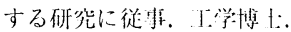

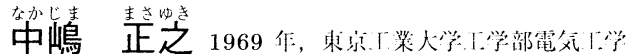

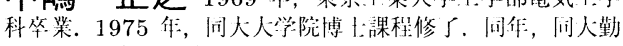
務。1983 作，间大像情報 L学研究施没助教授。1992 作,

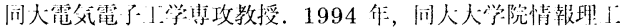
学研究科教授. 现低に符る。コンピュータグラフィックス, コンピュータアニメーション，西像処理の研究に従打。:

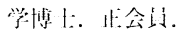

また，本提案手法を容易に利用可能にするためのライ ブラリ化も行っていく予定である.

\section{〔文献〕}

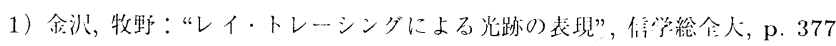
(1997).

2) Y. Dobashi. T. Yamamoto and T. Nishita: "Interactive Rendering Method for Displaying Shafts of Light", Pacific Graphics2000, pp. $31-47(2000)$.

3) H. W. Jansen and P. H.Christensen: "Efficient Simulation of Light Transport in Scenes with Participating Media using Photon Maps", Proc. SIGGRAPH'98, pp. 311-320 (1998).

4) H. E.Rushmeier and K. E.Torrance: "The Zonal Method for Calculating Light Intensities in The Presence of a Participating Medium", Comuputer Graphics. 21, 4, pp. 293-302 (1987)

5) N. Max: "Atmospheric Illumination and Shadows", Computer Graphics, 20, 4, pp. 117-124 (1986).

6）た橋，们本：“敬乱光強度のアダブティブサンブリングによるグラフィックス

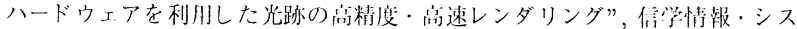
テムソサイエティ人会, D-12-30, p. 205 (2001).

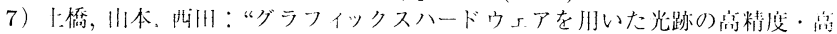
速レンダリング法”，映怗学忘，55，7, pp. 1019-1024 (2001).

8) T. Nishita, Y. Miyazaki and E. Nakamae: "A Shading Model for Atmospheric Scattering Considering Luminous Intensity Distribution of Light Sources", Computer Graphics, 21, 4, pp. 303-310 (1987). 